Check for updates

Cite this: RSC Adv., 2018, 8, 11778

\title{
Role of ceria in the improvement of NO removal of lanthanum-based perovskite-type catalysts
}

\begin{abstract}
Xiaochen Li and Hongwei Gao (DD *
Lanthanum-based perovskite-type oxides represented by $\mathrm{LaBO}_{3}(\mathrm{~B}=\mathrm{Co}, \mathrm{Fe}, \mathrm{Mn}$ ) have been thought to present strong limitations for practical application although they are active for catalytic removal of NO. Cerium (Ce) substitution has been extensively studied to modify the properties of perovskites. It is noted that a new phase of ceria $\left(\mathrm{CeO}_{2}\right)$ can be separated from perovskites when the doping ratio exceeds the solution limit $(x>\mathrm{S})$. This review outlines the relationship between the existence of $\mathrm{CeO}_{2}$ phase and catalytic activity. $\mathrm{CeO}_{2}$ dispersing on the lattice surface or small particles are beneficial for catalytic activity, but larger particles are adverse. Ce-doped $\mathrm{LaBO}_{3}$ perovskites exhibiting the best activity must contain additional $\mathrm{CeO}_{2}$ phases. In addition, $\mathrm{CeO}_{2}$-supported $\mathrm{LaBO}_{3}$ perovskite catalysts are discussed.
\end{abstract}

Received 16th January 2018 Accepted 19th March 2018

DOI: $10.1039 / \mathrm{c} 8 \mathrm{ra00456k}$

rsc.li/rsc-advances hydrothermal deactivation and are only active at high temperature while the second, noble metals, are costly and easily agglomerated during the reaction. In contrast to the above two catalysts, composite mixed oxides, especially perovskite-type catalyst with the general formula of $\mathrm{ABO}_{3}$, have considered as a group of promising catalysts for NO removal as they are lower price, mixed valence states of the transition metals and higher stability. ${ }^{17-19}$

Lanthanum-based perovskites $\left(\mathrm{LaBO}_{3}\right)$, some of which exhibit excellent performance for NO removal, ${ }^{20-22}$ have been extensively investigated. As far as we know, unmodified $\mathrm{LaBO}_{3}$ perovskites present strong limitations (e.g. comparatively small surface area and low catalytic activity at low temperatures) 21,22 $^{21}$ and therefore reliable technologies need to be developed. Among these technologies tackling aforementioned problems, we find that doping Ce into perovskite $\left(\right.$ e.g. $\left.\mathrm{La}_{0.6} \mathrm{Ce}_{0.4} \mathrm{CoO}_{3}\right)$ or $\mathrm{CeO}_{2}$ as a "support" (e.g. $\left.\mathrm{LaCoO}_{3} / \mathrm{CeO}_{2}\right)$ are effective. In addition, it have been reported that the solubility of Ce in $\mathrm{LaBO}_{3}$ perovskites is low and $\mathrm{CeO}_{2}$ appears in the mixed-oxides when $\mathrm{Ce}$ addition exceeds its solubility limit (S). The valence alternation ability of $\mathrm{Ce}^{3+} / \mathrm{Ce}^{4+}$ makes $\mathrm{CeO}_{2}$ a good oxygen reservoir which stores and releases oxygen under oxidizing and reducing conditions, respectively. ${ }^{23,24}$ In this review, $\mathrm{CeO}_{2}$ is focused because of its significant role in improving catalytic activity of $\mathrm{LaBO}_{3}$ perovskites catalysts. The roles played $\mathrm{CeO}_{2}$ by will be introduced by the following two topics: (i) $\mathrm{CeO}_{2}$ as separated phase (ii) $\mathrm{CeO}_{2}$ as the support.

\section{Description of lanthanum-based perovskite-type catalysts}

The perovskite-type oxides mentioned here adopt $\mathrm{LaBO}_{3}$ structure (Fig. 1), in which B-sites are occupied by small transition metals such as Fe, Mn. ${ }^{25-27}$ For the resulting compounds, each 


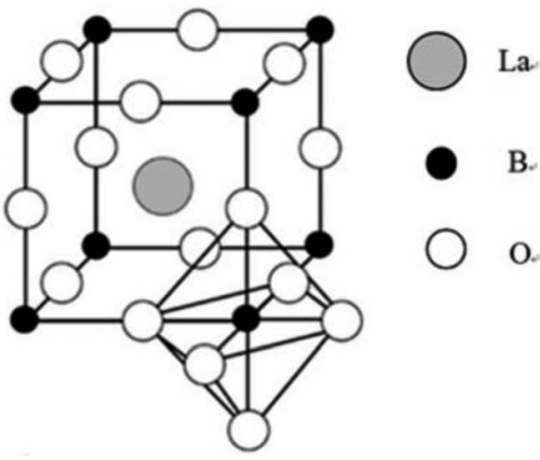

Fig. 1 Crystal structure of the $\mathrm{LaBO}_{3}$ perovskite oxide. ${ }^{4}$

La cation is surrounded by 12 oxygen anions whereas each $\mathrm{B}$ cation is surrounded by 6 oxygen anions. ${ }^{28}$ In the ideal unit cell where the atoms are packed closely, $\mathrm{La}-\mathrm{O}$ distance is equal to $a /$ $\sqrt{ } 2$ ( $a$ is the cubic unit cell parameter) while B-O distance is $a / 2$. Besides, La, B and O ions should satisfy the requirement that the value of tolerance factor $(t)^{28-30}$ is equal to 1 . The parameter is defined by the expression $t=\left(r_{\mathrm{La}}+r_{\mathrm{B}}\right) /\left\{\sqrt{ } 2\left(r_{\mathrm{B}}+r_{\mathrm{O}}\right)\right\}$, where $r_{\mathrm{La}}$, $r_{\mathrm{B}}$ and $r_{\mathrm{O}}$ correspond to the crystal radii for cations La and $\mathrm{B}$ and the anion $\mathrm{O}$, respectively. However, the perovskite structure is also found for lower values of $t$ in the range 0.75 to $1 .^{28,30}$ The simple perovskite structure could be partially replaced by foreign ions with appropriate size difference, preserving matrix perovskite structure. In such cases, the cubical structure can be distorted into tetragonal, rhombohedral, or other lower symmetries. ${ }^{29,30}$ Besides the ionic radii requirement, electroneutrality is another condition. For example, the substitution of $\mathrm{La}^{3+}$ cation in $\mathrm{LaMnO}_{3}$ with $\mathrm{Sr}^{2+}$ is accompanied by a change of the oxidation state of $\mathrm{Mn}$ cation $\left(\mathrm{Mn}^{3+} \rightarrow \mathrm{Mn}^{4+}\right)$ and exhibits oxidative non-stoichiometry. ${ }^{31}$ The substitution may stabilize an unusual oxidation state of the cation in position B and/or produce oxygen vacancies or structural defects. ${ }^{31-33}$ These excellent characteristics can enhance substantially the catalytic activity and therefore have frequently been exploited in perovskite-type catalysis.

Ce often appears as a good promoter in perovskite lattice because of its two different valence states $\mathrm{Ce}^{4+}$ or $\mathrm{Ce}^{3+}{ }^{3,34,35}$ The substitution of $\mathrm{La}^{3+}$ cation in $\mathrm{LaBO}_{3}$ with higher valence $\mathrm{Ce}^{4+}$ will affect indirectly the electronic state of the B-site ion. As mentioned above, $\mathrm{Sr}^{2+}$ are used to partially substitute the A-site ions in order to increase the basicity and to produce oxide anion vacancies by charge compensation. To get a better and clearer understanding about Ce doping, we take $\mathrm{LaCoO}_{3}$ as an example to explain the process of defect formation. Three reactions have been considered for Ce doping, ${ }^{36,37}$ the first two of which are for doping stoichiometric $\mathrm{LaCoO}_{3}$. The substitution of $\mathrm{La}^{3+}$ cation in $\mathrm{LaCoO}_{3}$ with $\mathrm{Ce}^{4+}$ leads to creation of $\mathrm{La}^{3+}$ vacancies (eqn (1)) or reduction of $\mathrm{Co}^{3+}$ to $\mathrm{Co}^{2+}$ (eqn (2)).

$$
\begin{gathered}
3 \mathrm{CeO}_{2}+4 \mathrm{La}_{\mathrm{La}}^{\times} \rightarrow 3 \mathrm{Ce}_{\mathrm{La}}^{\cdot}+\mathrm{V}_{\mathrm{La}}^{\prime \prime \prime}+2 \mathrm{La}_{2} \mathrm{O}_{3} \\
4 \mathrm{CeO}_{2}+4 \mathrm{La}_{\mathrm{La}}^{\times}+4 \mathrm{Co}_{\mathrm{Co}}^{\times} \rightarrow 4 \mathrm{Ce}_{\mathrm{La}}^{\cdot}+4 \mathrm{Co}_{\mathrm{Co}}^{\prime}+2 \mathrm{La}_{2} \mathrm{O}_{3}+\mathrm{O}_{2}
\end{gathered}
$$

However, as prepared $\mathrm{LaCoO}_{3}$ calcined at $\geq 900{ }^{\circ} \mathrm{C}$ is typically slightly reductively non-stoichiometric. ${ }^{38}$ Therefore, the third reaction that $\mathrm{Ce}$ is doped into the $\mathrm{LaCoO}_{3}$ lattice containing oxygen lattice vacancies was considered. This means that those oxygen vacancies were refilled.

$$
2 \mathrm{La}_{\mathrm{La}}^{\times}+2 \mathrm{CeO}_{2}+\mathrm{V}_{O}^{\ddot{*}} \rightarrow 2 \mathrm{Ce}_{\mathrm{La}}^{\cdot}+\mathrm{La}_{2} \mathrm{O}_{3}+\mathrm{O}_{\mathrm{O}}^{\times}
$$

These defects caused by Ce doping lead to the fact that perovskite-type oxides show promising structural, surface and catalytic properties for catalyst application. In addition, supported lanthanum-based perovskite-type catalysts, e.g. $\mathrm{LaBO}_{3} /$ $\mathrm{CeO}_{2}$, were also extensively studied.

\section{3. $\mathrm{CeO}_{2}$ as separated phase}

Among various perovskites, lanthanum-based samples represented by $\mathrm{LaBO}_{3}(\mathrm{~B}=\mathrm{Co}, \mathrm{Fe}, \mathrm{Mn})$ are known to be excellent catalysts for NO removal. ${ }^{21,22}$ Also, it has been reported that the Ce often appeared as a crucial component for perovskites because of its two different valence states $\mathrm{Ce}^{4+}$ or $\mathrm{Ce}^{3+}$, which is important to the catalytic reaction. This is the reason why people have been paying increasing attention to Ce-doped $\mathrm{LaBO}_{3}$ perovskites.

For a low Ce content (which is below its solubility in perovskite structure), Ce can be incorporated into the $\mathrm{LaBO}_{3}$ lattice to form a solid solution. The valence change of $\mathrm{B}$ is complicated due to the addition of Ce. The substitution of $\mathrm{La}^{3+}$ in $\mathrm{LaBO}_{3}$ with $\mathrm{Ce}^{3+}$ result in no change of valence state of $\mathrm{B}$ ions $\left(\mathrm{B}^{n+}\right)$. The higher valence $\mathrm{Ce}^{4+}$ substitution lead to the fact that electroneutrality of the lattice is not maintained. As such, cation vacancies are formed and valence state of B ions is changed. No interstitial oxygen ions, however, are detected because perovskite lattice cannot accommodate them. ${ }^{39,40}$ For high Ce content (which exceed their solubility limit in perovskite structure), $\mathrm{CeO}_{2}$ are formed and segregated from perovskite oxides. The extra phase, $\mathrm{CeO}_{2}$, is either highly dispersed on the surface of $\mathrm{La}_{1-x} \mathrm{Ce}_{x} \mathrm{BO}_{3}$ for comparatively low Ce content or found as larger particles for higher Ce content. The presence of $\mathrm{CeO}_{2}$ result in appearance of Ce vacancy sites or migration of (excess) B ions outside the perovskite lattice to yield $\mathrm{B}_{y} \mathrm{O}_{x}$ or both. ${ }^{41}$ In this case, $\mathrm{CeO}_{2}$ are believed to play a key role in enhancement of catalytic performance.

\subsection{Ce doped $\mathrm{LaCoO}_{3}$}

The influence of Ce substitution on structural characteristics has been discussed in previous literatures. ${ }^{42-48}$ Based on the Xray diffraction (XRD) results, Fig. 2, no peaks of $\mathrm{CeO}_{2}$ are detected when Ce addition was below 0.05 , indicating that the doped Ce atoms might have embodied into the $\mathrm{LaCoO}_{3}$ lattice to form a solid solution. For $x=0$ and 0.05 , the structures were the rhombohedral $\mathrm{LaCoO}_{3}$-type (JCPDS 25-1060). As the content of doped Ce increasing, the other minor phase, $\mathrm{CeO}_{2}$, was also detected in addition to the major $\mathrm{ABO}_{3}$ perovskite phase. This is attributed to that Ce addition exceeds its solubility limit $(x \geq$ 0.1). ${ }^{45,46}$ Although no $\mathrm{Co}_{3} \mathrm{O}_{4}$ peaks were detected in the XRD 


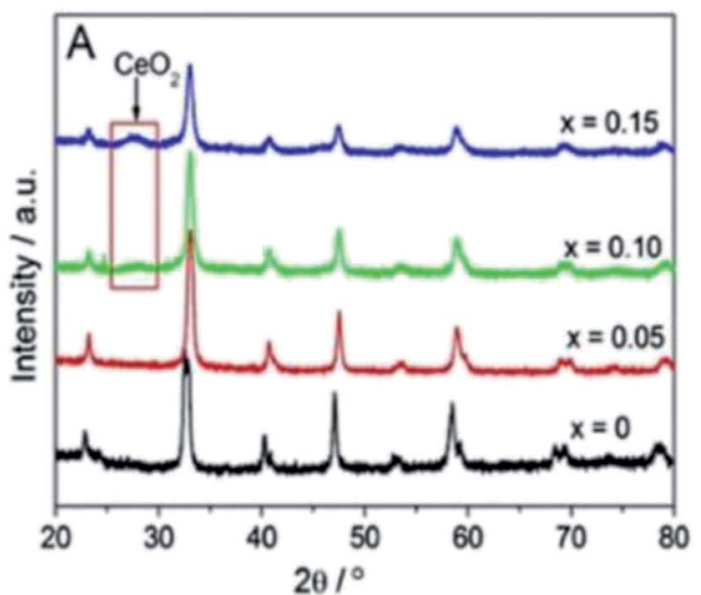

Fig. 2 XRD patterns of the $\mathrm{La}_{1-x} \mathrm{Ce}_{x} \mathrm{CoO}_{3}$ perovskites $(x=0,0.05$, 0.10 and 0.15$)^{46}$

diffraction spectroscopy, $\mathrm{Co}_{3} \mathrm{O}_{4}$ is proposed to be separated from perovskite oxides accompanying with the separation of $\mathrm{CeO}_{2}$ phase, which has been proved by previous literatures. ${ }^{\mathbf{4 3 4 5 , 4 7}}$ According to Erdenee's study on samples with $x=$ 0.2 and $0.4,{ }^{43}$ the structure of $\mathrm{LaCoO}_{3}$ transforms from rhombohedral to cubic and peaks corresponding to $\mathrm{Co}_{3} \mathrm{O}_{4}$ and $\mathrm{CeO}_{2}$ were visible. The severe lattice distortion perhaps leads to form more oxygen vacancies. ${ }^{42}$ Table 1 lists the values of specific surface area (ssa) of $\mathrm{La}_{1-x} \mathrm{Ce}_{x} \mathrm{CoO}_{3}$ perovskites. It is observed that the increment of the ssa values of the obtained perovskites follows the sequence: $\mathrm{LaCoO}_{3}\left(\mathrm{ssa}=8.9 \mathrm{~m}^{2} \mathrm{~g}^{-1}\right)<\mathrm{La}_{0.7} \mathrm{Ce}_{0.3^{-}}$ $\mathrm{CoO}_{3}\left(\mathrm{ssa}=9.8 \mathrm{~m}^{2} \mathrm{~g}^{-1}\right)<\mathrm{La}_{0.6} \mathrm{Ce}_{0.4} \mathrm{CoO}_{3}\left(\mathrm{ssa}=10.8 \mathrm{~m}^{2} \mathrm{~g}^{-1}\right)<$ $\mathrm{La}_{0.8} \mathrm{Ce}_{0.2} \mathrm{CoO}_{3}\left(\mathrm{ssa}=11.0 \mathrm{~m}^{2} \mathrm{~g}^{-1}\right)<\mathrm{La}_{0.95} \mathrm{Ce}_{0.05} \mathrm{CoO}_{3}(\mathrm{ssa}=$ $\left.11.4 \mathrm{~m}^{2} \mathrm{~g}^{-1}\right)<\mathrm{La}_{0.9} \mathrm{Ce}_{0.1} \mathrm{CoO}_{3}\left(\mathrm{ssa}=12.6 \mathrm{~m}^{2} \mathrm{~g}^{-1}\right)$. So we reach the conclusion that substituted samples have a larger ssa values than pure perovskites and the enhancement was not linear with substitution concentration. When Ce addition was below its solubility limit $(x \leq 0.1)$, it was noticed that the value of ssa significantly increase as pore volume was enlarged. However, with the increased proportion of Ce, their ssa decrease, which might be related to that the $\mathrm{CeO}_{2}$ was segregated out and filled in the pores of the perovskite. ${ }^{46}$

In addition to above-mentioned physical structures, the effect of Ce substitution on redox properties have also been discussed in this paper. Firstly, it has been reported that partial substitution with Ce can affect the surface characteristics which are always more important than lattice. The surface characteristics obtained from X-ray photoelectron spectroscopy (XPS) has been observed in the reports of Erdenee et al. ${ }^{43}$ and Wen et al. ${ }^{45}$ In their work, no change of La valence state $\left(\mathrm{La}^{3+}\right)$ was detected

Table 1 Brunauer-Emmett-Teller (BET) analysis results of $\mathrm{La}_{1-x} \mathrm{Ce}_{x^{-}}$ $\mathrm{CoO}_{3}$ perovskites calcined at $700{ }^{\circ} \mathrm{C}$ for $2 \mathrm{~h}^{45}$

$\mathrm{La}_{1-x} \mathrm{Ce}_{x} \mathrm{CoO}_{3}$

$\begin{array}{rlllll}x=0 & x=0.05 & x=0.1 & x=0.2 & x=0.3 \quad x=0.4\end{array}$

$\begin{array}{lllllll}\text { SSA }\left(\mathrm{m}^{2} \mathrm{~g}^{-1}\right) & 8.9 & 11.4 & 12.6 & 11.0 & 9.8 & 10.8\end{array}$
Table 2 The percentage of adsorption oxygen obtained from XPS ${ }^{45}$

\begin{tabular}{lllllll}
\hline $\mathrm{La}_{1-x} \mathrm{Ce}_{x} \mathrm{CoO}_{3}$ & & & & & \\
\hline & $x=0$ & $x=0.05$ & $x=0.1$ & $x=0.2$ & $x=0.3$ & $x=0.4$ \\
$\%$ & 46.6 & 42.2 & 43.5 & 48.4 & 39.8 & 38.3
\end{tabular}

when La was substituted with Ce. But they all agreed that the trivalent Co ion is partly changed. As has been reported by Wen et al. ${ }^{45}$ when the doping ratio was below 0.1 , tetravalent Ce ions were fully dissolved into the perovskite structure so that electronic unbalance was generated. As a result, a part of $\mathrm{Co}^{3+}$ in the B-site became $\mathrm{Co}^{2+}$ or $\mathrm{La}^{3+}$ vacancies were created as a charge compensation mechanism. ${ }^{36,37}$ When $x$ was larger than 0.1 , the average oxidation state of the Co cation increased because the existence of $\mathrm{CeO}_{2}$ might lead to deficiency of A-cation. Of course, they also showed XPS spectra of O 1s. According to ref. 43,45 and 47 , there are three different forms of oxygen including lattice oxygen $\left(\mathrm{O}_{\text {latt }}\right)$, adsorbed oxygen $\left(\mathrm{O}_{\text {ads }}\right)$, and surface adsorbed water species. Wen et al. ${ }^{45}$ found that the $\mathrm{La}_{0.8} \mathrm{Ce}_{0.2} \mathrm{CoO}_{3}$ achieved the highest percentage of adsorption oxygen which participated in oxidation reactions. It is generally accepted that among $\mathrm{Ce}$ doped $\mathrm{LaCoO}_{3}$ samples, $\mathrm{La}_{0.8} \mathrm{Ce}_{0.2} \mathrm{CoO}_{3}$ shows the best activity. ${ }^{43,45}$ However, we cannot directly draw the conclusion that the improvement of catalytic activities are due to high amount of adsorbed oxygen, owing to the fact that although the perovskite $\mathrm{LaCoO}_{3}$ also gets high amount of adsorbed oxygen (Table 2), its activity is low. Additionally, it was proved that Ce ions were present in the trivalent and tetravalent form. ${ }^{43,46,47}$ The relative concentration of $\mathrm{Ce}^{3+}$, defined as $\mathrm{Ce}^{3+} /$ $\left(\mathrm{Ce}^{3+}+\mathrm{Ce}^{4+}\right)$, was listed in Table 3 . It varied from $19.2 \%$ to $21.0 \%$, indicating that $\mathrm{Ce}^{4+}$ was dominant in all the samples. Secondly, a result of temperature programmed reduction of $\mathrm{H}_{2}$ $\left(\mathrm{H}_{2}\right.$-TPR) experiment investigating effect of Ce addition on the redox ability of $\mathrm{LaCoO}_{3}$ is shown in Fig. 3. The literature ${ }^{46}$ also displayed the $\mathrm{H}_{2}$-TPR profiles of $\mathrm{La}_{1-x} \mathrm{Ce}_{x} \mathrm{CoO}_{3}$, in which two obvious reduction peaks were observed, which could be attributed to the reduction of $\mathrm{Co}^{3+}$ to $\mathrm{Co}^{2+}$ and $\mathrm{Co}^{2+}$ to $\mathrm{Co}^{0}$, respectively. As was seen from Fig. 3, two reduction peaks respectively located at about $400{ }^{\circ} \mathrm{C}$ and $600{ }^{\circ} \mathrm{C}$. When a certain amount of Ce was introduced into the $\mathrm{LaCoO}_{3}$ perovskite structure, the two peaks moved forward to lower temperature direction correspondingly, indicating that $\mathrm{Ce}^{4+}$ insertion increased the catalyst reducibility. In other word, Ce-doped catalysts showed a better reducibility as the reduction temperatures of these catalysts were lower than pure $\mathrm{LaCoO}_{3}$. And the sample with $\mathrm{La}_{1-x} \mathrm{Ce}_{x^{-}}$ $\mathrm{CoO}_{3}(x=0.2)$ leads to the highest decrease in the reduction peak temperatures. This may be because (1) it creates an easier

Table 3 The relative concentration of $\mathrm{Ce}^{3+}$ of $\mathrm{La}_{1-x} \mathrm{Ce}_{x} \mathrm{CoO}_{3}$ catalysts ${ }^{47}$

$\mathrm{La}_{1-x} \mathrm{Ce}_{x} \mathrm{CoO}_{3}$

$\begin{array}{rlllll} & x=0 & x=0.05 & x=0.1 & x=0.3 & x=0.5 \\ \mathrm{Ce}^{3+} /\left(\mathrm{Ce}^{3+}+\mathrm{Ce}^{4+}\right)(\%) & - & 20.6 & 21.0 & 20.3 & 19.2\end{array}$ 
reducibility of the $\mathrm{Co}^{3+}$ into $\mathrm{Co}^{2+}$ and, (2) $\mathrm{Ce}^{4+}$ increases the number of cation vacancies within the lattice.

According to Wen's paper, ${ }^{45}$ the $\mathrm{La}_{1-x} \mathrm{Ce}_{x} \mathrm{CoO}_{3}$ samples synthesized through a citrate show the highest conversion $(80 \%)$ at about $300^{\circ} \mathrm{C}$ in a flow of $\mathrm{NO}+\mathrm{O}_{2}+$ He when $x$ was 0.2 . However, the catalytic activities decreased at higher $x$ values. They thought that these factors including the presence of $\mathrm{CeO}_{2}$ and the decrease of adsorbed oxygen amount caused the decrease of activity. Combined with his results of XRD, when $x>$ 0.1, the peaks of $\mathrm{CeO}_{2}$ were observed. This means that small $\mathrm{CeO}_{2}$ appeared in the mixed-oxide. Thus, it is concluded that the existence of small $\mathrm{CeO}_{2}$ nano-particles is beneficial to the improvement of catalytic activities, but catalytic activities decreased because larger particles are formed at higher $\mathrm{Ce}$ content.

\section{2 $\mathrm{Ce}$ doped $\mathrm{LaFeO}_{3}$}

Like $\mathrm{La}_{1-x} \mathrm{Ce}_{x} \mathrm{CoO}_{3}$ samples, a series of $\mathrm{La}_{1-x} \mathrm{Ce}_{x} \mathrm{FeO}_{3}$ perovskite-type oxide catalysts are also characterized by XRD, BET, XPS and TPR to illustrate the influence of Ce substitution. In these literatures, ${ }^{49-51}$ it is found that the substitution of La by Ce can increase the value of ssa and change the reducibility of $\mathrm{Fe}$ cation and $\mathrm{Fe}^{4+} / \mathrm{Fe}^{3+}$ ratios. The influence of Ce substitution on $\mathrm{LaFeO}_{3}$ is very similar to that on $\mathrm{LaCoO}_{3}$. Therefore, changes in its physicochemical properties are not explained in this part, but effect of catalytic performances is paid more attention here.

Giannakas et $a .^{50}$ investigated and compared the catalytic performance of $\mathrm{LaFeO}_{3}, \mathrm{La}_{0.85} \mathrm{Sr}_{0.15} \mathrm{FeO}_{3}, \mathrm{La}_{0.8} \mathrm{Sr}_{0.1} \mathrm{Ce}_{0.1} \mathrm{FeO}_{3}$ and $\mathrm{La}_{0.8} \mathrm{Ce}_{0.2} \mathrm{FeO}_{3}$ which were prepared via a reverse micelles microemulsion route for NO reduction by $\mathrm{CO}$, finding that the full sequence of catalytic activity of tested solids is $\mathrm{La}_{0.8} \mathrm{Ce}_{0.2^{-}}$ $\mathrm{FeO}_{3}>\mathrm{La}_{0.8} \mathrm{Sr}_{0.1} \mathrm{Ce}_{0.1} \mathrm{FeO}_{3}>\mathrm{La}_{0.85} \mathrm{Sr}_{0.15} \mathrm{FeO}_{3} \geq \mathrm{LaFeO}_{3}$. They pointed that (1) the above sequence is in accordance with the sequence of increment of ssa of the solids and, (2) $\mathrm{La}_{0.8} \mathrm{Ce}_{0.2^{-}}$ $\mathrm{FeO}_{3}$ and $\mathrm{La}_{0.8} \mathrm{Sr}_{0.1} \mathrm{Ce}_{0.1} \mathrm{FeO}_{3}$ show much higher catalytic activity than the solids containing no Ce, which may be caused by the presence of $\mathrm{CeO}_{2}$ phase in these two solids. Qin et al. ${ }^{51}$ also reported that catalytic reaction of $\mathrm{La}_{1-x} \mathrm{Ce}_{x} \mathrm{FeO}_{3}$ for NO

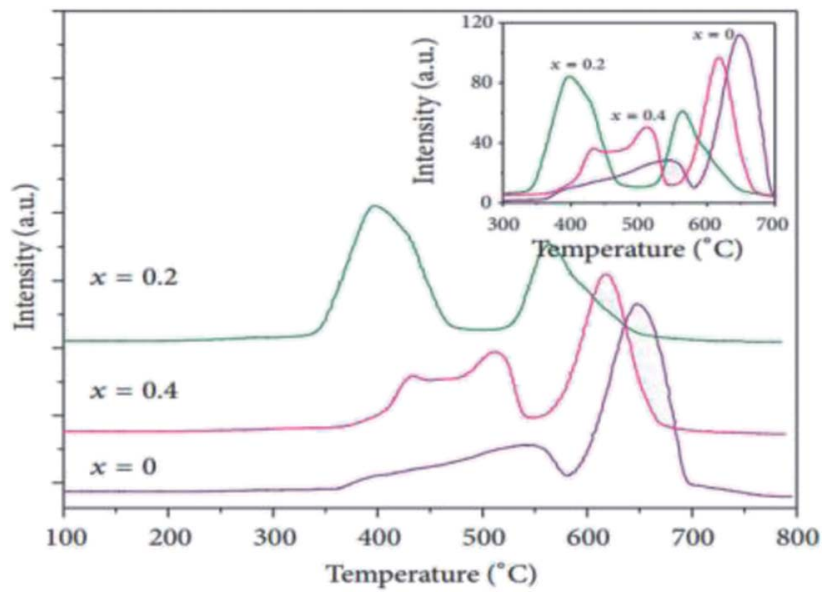

Fig. $3 \mathrm{H}_{2}$-TPR profiles of the $\mathrm{La}_{1-x} \mathrm{Ce}_{x} \mathrm{CoO}_{3}(\mathrm{O} \leq x \leq 0.4)$ catalysts. ${ }^{43}$ reduction with $\mathrm{CO}$ and illustrated the influence of Ce substitution on $\mathrm{SO}_{2}$ resistance. It was found that although $\mathrm{LaFeO}_{3}$ exhibited an excellent catalytic performance without $\mathrm{SO}_{2}(100 \%$ $\mathrm{NO}$ conversion at $500{ }^{\circ} \mathrm{C}$ ), catalytic reaction decreased drastically when $\mathrm{SO}_{2}$ gas was added to the $\mathrm{CO}+\mathrm{NO}$ system(conversion rate decreased to $40-50 \%$ after approximately $100 \mathrm{~min}$ ). Doping a certain amount of Ce into the $\mathrm{LaFeO}_{3}$ perovskite structure could obviously improve the $\mathrm{SO}_{2}$ resistance. For example, $\mathrm{La}_{0.6} \mathrm{Ce}_{0.4} \mathrm{FeO}_{3}$ sample maintained a conversion rate of $80 \%$ during the latter $270 \mathrm{~min}$ after addition of $\mathrm{SO}_{2}$ gas into the $\mathrm{CO}+$ NO reaction system. The reason was suggested to be the addition of $\mathrm{Ce}^{4+}$ which could prevent the adverse effect of $\mathrm{SO}_{2}$ on the $\mathrm{LaFeO}_{3}$ perovskite by absorbing $\mathrm{SO}_{2}$ and forming $\mathrm{Ce}\left(\mathrm{SO}_{4}\right)_{2}$. Thus, the presence of $\mathrm{Ce}^{4+}$ is the key factor to the improvement of $\mathrm{SO}_{2}$ resistance in $\mathrm{LaFeO}_{3}$ perovskite catalysts.

Recently, attapulgite (ATP) was considered as support for $\mathrm{La}_{1-x} \mathrm{Ce}_{x} \mathrm{FeO}_{3}$ catalysts, not only because of its inexpensive but also for its adsorption of many pollutants. A recent research ${ }^{52}$ on $\mathrm{La}_{1-x} \mathrm{Ce}_{x} \mathrm{FeO}_{3} / \mathrm{ATP}$ was conducted for testing its photocatalytic reduction of $\mathrm{NO}$ at low temperature. Following investigation on photo-SCR activity and stability of $\mathrm{La}_{1-x} \mathrm{Ce}_{x} \mathrm{FeO}_{3} /$ ATP samples (Fig. 4) proves that the substitution of Ce is helpful for the improvement of catalytic performance. It is noteworthy that the conversion rate of NO reaches close to $80 \%$ when Ce doping amount is 0.3 at room temperature. Combined with $\mathrm{XRD}$ results, $\mathrm{CeO}_{2}$ is precipitated from the solid solution when the Ce doping ratio is 0.3 . This implies that the existence of $\mathrm{CeO}_{2}$ is no harm for $\mathrm{NO}_{x}$ reduction.

Besides the NO removal, $\mathrm{La}_{1-x} \mathrm{Ce}_{x} \mathrm{FeO}_{3}$ was also considered as promising catalyst in some reactions. For example, Xiang et al. ${ }^{49}$ reported that the temperature of $\mathrm{CH}_{4}$ conversion at $90 \%$ was as low as $510^{\circ} \mathrm{C}$ when $x=0.3$. According to Ma's report, ${ }^{53}$ in the case of $x=0.5$, the conversion of $\mathrm{CO}$ is about $68 \%$ at $530^{\circ} \mathrm{C}$.

\subsection{Ce doped $\mathrm{LaMnO}_{3}$}

As mentioned earlier, we have systematically studied the effect of $\mathrm{Ce}$ in $\mathrm{La}_{1-x} \mathrm{Ce}_{x} \mathrm{CoO}_{3}$ and $\mathrm{La}_{1-x} \mathrm{Ce}_{x} \mathrm{FeO}_{3}$ perovskites.

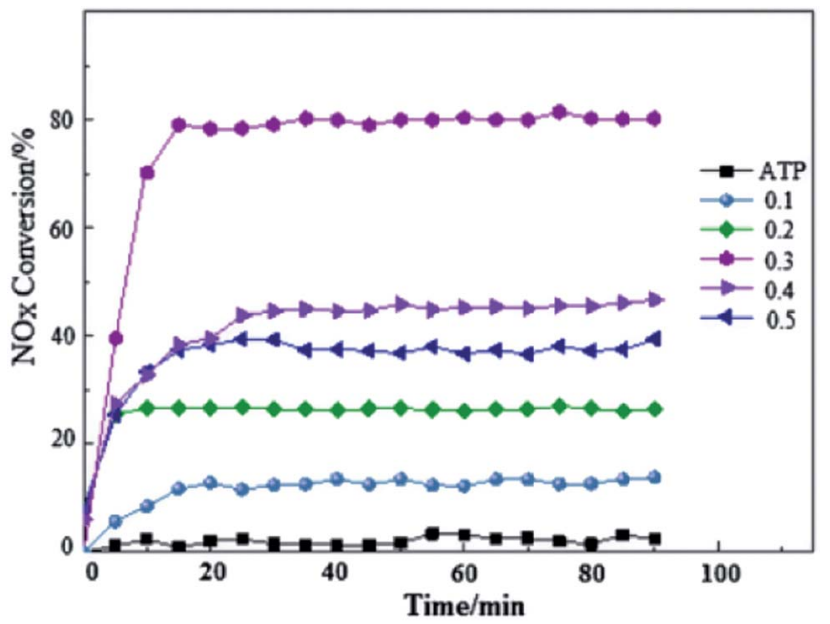

Fig. 4 Photo-SCR denitrification activity and stability of $\mathrm{La}_{1-x} \mathrm{Ce}_{x^{-}}$ $\mathrm{FeO}_{3} /$ ATP $(x=0.1-0.5) .^{52}$ 
Therefore, the properties of $\mathrm{La}_{1-x} \mathrm{Ce}_{x} \mathrm{MnO}_{3}$ are not discussed here, because the influences of Ce in $\mathrm{La}_{1-x} \mathrm{Ce}_{x} \mathrm{MnO}_{3}$ are similar to that in former two perovskites except that segregation of $\mathrm{CeO}_{2}$ is not accompanied by segregation of some manganese oxide according to cases. ${ }^{\mathbf{4 3 5 4 - 5 6}}$ This may be ascribed to that manganese oxide can be dissolved in the segregated $\mathrm{CeO}_{2} \cdot{ }^{54}$ In this part, the simultaneous substitution of $\mathrm{Ce}$ at the A-site and other ions $\left(\mathrm{B}^{\prime}\right)$ at the $\mathrm{B}$-site in a $\mathrm{LaMnO}_{3}$ lattice will be made concentrates mainly.

For $\mathrm{La}_{1-x} \mathrm{Ce}_{x} \mathrm{Mn}_{1-y} \mathrm{~B}_{y}^{\prime} \mathrm{O}_{3}$ catalysts, the effect of the substitution of La by Ce in these catalysts is more complex than that in $\mathrm{La}_{1-x} \mathrm{Ce}_{x} \mathrm{MnO}_{3}$, since the $\mathrm{Ce}$ cation not only changes the reducibility of $\mathrm{Mn}$ cation $\left(\mathrm{Mn}^{3+} \leftrightarrow \mathrm{Mn}^{4+}\right)$, but also may affect the oxidation state of the $\mathrm{B}^{\prime}$ cation. In the case of $\mathrm{La}_{1-x} \mathrm{Ce}_{x} \mathrm{Mn}_{1-y} \mathrm{~B}_{y}^{\prime} \mathrm{O}_{3}$, the redox couple can be $\mathrm{Ce}^{4+} / \mathrm{Ce}^{3+}, \mathrm{Mn}^{4+} /$ $\mathrm{Mn}^{3+}$ and $\mathrm{B}^{\prime n+} / \mathrm{B}^{\prime(n-1)+}$ since oxidation state of $\mathrm{B}^{\prime}$ cation may be variable. According to He's paper, ${ }^{57}$ the reaction $\left(\mathrm{Ce}^{3+}+\mathrm{Cu}^{2+} \rightarrow\right.$ $\left.\mathrm{Ce}^{4+}+\mathrm{Cu}^{+}\right)$taken place during the preparation process of the $\mathrm{La}_{0.8} \mathrm{Ce}_{0.2} \mathrm{Mn}_{0.6} \mathrm{Cu}_{0.4} \mathrm{O}_{3}$ catalysts. The presence of $\mathrm{Cu}^{+}$and its redox equilibrium $\left(\mathrm{Cu}^{+} \leftrightarrow \mathrm{Cu}^{2+}\right)$ would facilitate the NO adsorption and reduction by CO. Similarly, Tarjomannejad et $a l .{ }^{58}$ studied the $\mathrm{LaMn}_{1-x} \mathrm{Fe}_{x} \mathrm{O}_{3}$ and $\mathrm{La}_{0.8} \mathrm{Ce}_{0.2} \mathrm{Mn}_{0.3} \mathrm{Fe}_{0.7} \mathrm{O}_{3}$ perovskites catalysts, finding that the substitution of $\mathrm{La}^{3+}$ by $\mathrm{Ce}^{4+}$ result in decrease of $\mathrm{Mn}^{4+} / \mathrm{Mn}^{3+}$ and $\mathrm{Fe}^{4+} / \mathrm{Fe}^{3+}$ ratios. Of course, the substituted samples can also lead to the formation of oxygen vacancies and the increase of $\mathrm{O}_{\text {ads }} / \mathrm{O}_{\text {latt }}$ ratio. An integration of all these factors resulted in the enhancement of catalytic activity ( $90 \% \mathrm{NO}$ conversion at $\left.323{ }^{\circ} \mathrm{C}\right)$. In addition, if the $\mathrm{B}^{\prime}$ cation exists in a permanent valence state, $\mathrm{Ce}^{4+} / \mathrm{Ce}^{3+}$ and $\mathrm{Mn}^{4+} / \mathrm{Mn}^{3+}$ are the redox couples. The role of Ce is just to adjust the valence state of $\mathrm{Mn}$ cation or/and the ratio of $\mathrm{O}_{\text {ads }} / \mathrm{O}_{\text {latt }}$. However, the catalytic performance of $\mathrm{La}_{1-x} \mathrm{Ce}_{x} \mathrm{Mn}_{1-y} \mathrm{~B}_{y}^{\prime} \mathrm{O}_{3}$ samples have no relation to whether the valence state is varied or not. Sometimes the $\mathrm{B}^{\prime}$ cation with a varied valence state can promote the catalytic reaction, ${ }^{57,58}$ sometimes inhibit. In the literature, ${ }^{59}$ the substitution of $\mathrm{Mn}$ by $\mathrm{Co}$ in $\mathrm{La}_{0.8} \mathrm{Ce}_{0.2} \mathrm{MnO}_{3}$ catalysts results in decreasing catalyst activity.

Besides, it has been reported that preparation methods interfere with the generation of $\mathrm{CeO}_{2}$ phase. In the paper, ${ }^{57}$ a considerable amount of $\mathrm{CeO}_{2}$ was found by XRD in the $\mathrm{La}_{0.8} \mathrm{Ce}_{0.2} \mathrm{Cu}_{0.4} \mathrm{Mn}_{0.6} \mathrm{O}_{3}$ and $\mathrm{La}_{0.8} \mathrm{Ce}_{0.2} \mathrm{Ag}_{0.4} \mathrm{Mn}_{0.6} \mathrm{O}_{3}$ samples synthesized by sol-gel method, but not in samples synthesized by the reverse microemulsion method.

\section{4. $\mathrm{CeO}_{2}$ as the support}

Aiming at resolving the problem that powder perovskites have much lower surface area, the scheme that perovskites are dispersed on thermally stable supports has been adopted and is being put into operation. Presently, perovskites are often supported on $\mathrm{Al}_{2} \mathrm{O}_{3}, \mathrm{CeO}_{2}$, attapulgite and other supports. ${ }^{60-64}$ Among a variety of support materials, $\mathrm{CeO}_{2}$ is one of the most popular supports because of its particular redox property. These supported perovskite oxides are usually prepared by impregnation methods and their performances depend closely on the support. In the paper, ${ }^{65}$ Zhang et al. investigated and compared the catalytic performance of $\mathrm{LaMnO}_{3} / \mathrm{CeO}_{2}$ and $\mathrm{LaMnO}_{3} / \mathrm{TiO}_{2}$ for the SCR of $\mathrm{NO}$ by $\mathrm{NH}_{3}$ in the presence of $\mathrm{O}_{2}$, finding that the former showed higher activity than the latter. The reason was suggested to be the difference of support. The phenomenon that $\mathrm{TiO}_{2}$ supporting led to a remarkable decrease in redox capacity, contrasting with the pure $\mathrm{LaMnO}_{3}$, has been also reported by Zhang et al. ${ }^{65}$ Thus, the conclusion that the catalytic performance of all supported samples can be higher than that of $\mathrm{ABO}_{3}$ perovskite alone is wrong.

Another factor for catalytic performance of supported samples is preparation method. $\mathrm{H}_{2}$-TPR experiment has been done to investigate the structure and reducibility of the catalysts prepared by two methods. ${ }^{66}$ The result shown in Fig. 5 indicated that preparation method had relation to the amount of $\mathrm{H}_{2}$ consumed, and it was suggested that $\mathrm{LaMnO}_{3} / \mathrm{CeO}_{2}$ prepared by the dry impregnation (DI) method showed higher activity than that by the precipitation-deposition (PD) method. In order to find the reason, the catalysts were characterized by XRD, BET and EXAFS. In the result of XRD, the peaks corresponding to the perovskite were detected for $\mathrm{LaMnO}_{3} / \mathrm{CeO}_{2}-\mathrm{PD}$ catalysts but hardly detected for the $\mathrm{LaMnO}_{3} / \mathrm{CeO}_{2}$-DI catalysts, indicating that $\mathrm{LaMnO}_{3}$ perovskite phases were highly dispersed on the $\mathrm{CeO}_{2}$ support. The BET surface areas of $\mathrm{LaMnO}_{3} / \mathrm{CeO}_{2}$-DI $\left(46 \mathrm{~m}^{2}\right.$ $\left.\mathrm{g}^{-1}\right)$ was lower than that of $\mathrm{LaMnO}_{3} / \mathrm{CeO}_{2}-\mathrm{PD}\left(68 \mathrm{~m}^{2} \mathrm{~g}^{-1}\right)$. The formation of a perovskite oxide phase for the $\mathrm{LaMnO}_{3} / \mathrm{CeO}_{2}$ catalysts was confirmed by the EXAFS studies. Combined with the $\mathrm{H}_{2}$-TPR study results, they propose that the higher activity may be ascribed to the strong interaction between the perovskite phase and the $\mathrm{CeO}_{2}$ support although this catalyst has smaller surface area. Oppositely, Alifanti et al. ${ }^{67}$ concluded that there was no interaction between the support and the elements of the perovskite.

In addition, the morphology of $\mathrm{CeO}_{2}$ has also a great influence on the catalytic activity, which has been studied by Wang et $a{ }^{68}$ It was found that the supported catalysts were more active than the unsupported catalyst $\left(\mathrm{La}_{0.8} \mathrm{Ce}_{0.2} \mathrm{MnO}_{3}\right)$ and $\mathrm{La}_{0.8} \mathrm{Ce}_{0.2} \mathrm{MnO}_{3} / \mathrm{CeO}_{2}$ nanopolyhedra exhibited the higher catalytic activity than the other two morphologies of $\mathrm{CeO}_{2}$

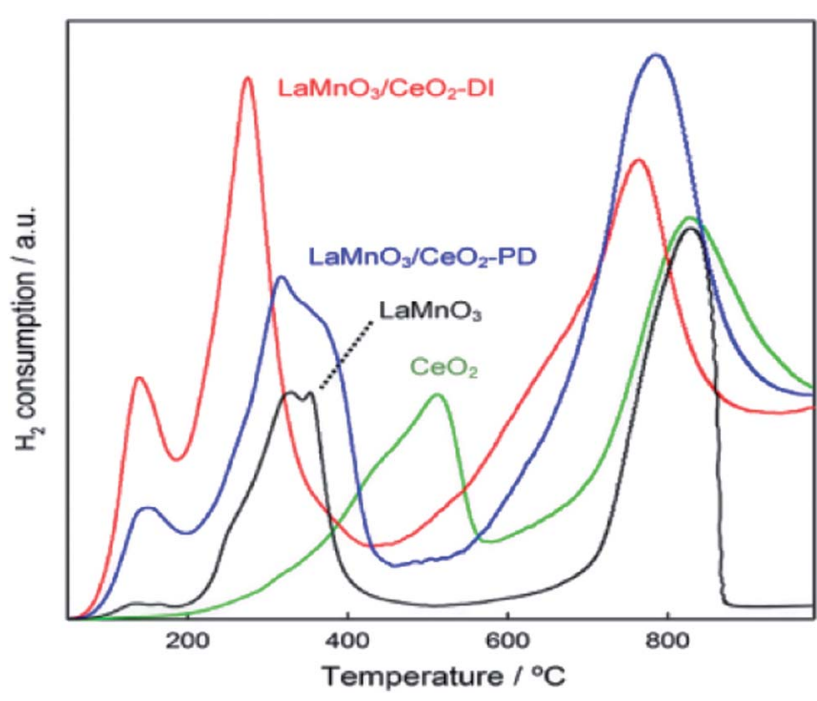

Fig. $5 \mathrm{H}_{2}$-TPR profiles of $\mathrm{LaMnO}_{3} / \mathrm{CeO}_{2}$ catalysts and $\mathrm{LaMnO}_{3} .{ }^{66}$ 
supported samples. The results described above are possible due to higher specific surface area and larger number of oxygen vacancies.

In summary, the modification method of perovskite oxides is effective for improving their catalytic activity, even though the promotion mechanism is still not clearly explained. Such a supported perovskite-type catalysts can have wide application prospects for the possibility of increasing its activity by simple preparation methods.

\section{Conclusion}

For Ce doped $\mathrm{LaBO}_{3}(\mathrm{~B}=\mathrm{Co}, \mathrm{Fe}, \mathrm{Mn})$, all catalysts exhibit relatively larger specific surface areas compared with pure perovskites. The introduction of Ce changes the reducibility of $\mathrm{B}$ cations and $\mathrm{B}^{n+} / \mathrm{B}^{(n-1)+}$ ratios and these factors induce the generation of crystal lattice defects which lead to higher catalytic activities. This review outlined the relationship between the existence of $\mathrm{CeO}_{2}$ phase and catalytic activity. When the Ce addition is below its solubility in perovskite structure $(x \leq S)$, Ce atoms can be totally incorporated in the perovskite lattice. Of course, Ce substitution at higher levels $(x>S)$ can lead to the formation of separated $\mathrm{CeO}_{2}$ phase. $\mathrm{CeO}_{2}$ is either highly dispersed on the lattice surface or is found as larger particles. The former amorphous $\mathrm{CeO}_{2}$ cannot be detected by XRD, while the latter can be done. ${ }^{41}$ What is more, it is found that Ce content of perovskite-type catalysts exhibiting the best activity exceeds its solubility in perovskites, indicating the presence of $\mathrm{CeO}_{2} \cdot \mathrm{CeO}_{2}$, however, does not show good catalytic activity by itself. ${ }^{4,69}$ This means that the effect of separated $\mathrm{CeO}_{2}$ on the catalytic performance is an indirect one, i.e., by regulating the $\mathrm{B}^{n+} / \mathrm{B}^{(n-1)+}$ ratios and by forming $\mathrm{B}_{y} \mathrm{O}_{x}$ phase. The interaction between different phases may also play a key role in improving catalytic activity to some extent. Nonetheless, it is found that as the content of doped Ce increasing, catalytic activity begins to decrease slightly. Thus, the $\mathrm{CeO}_{2}$ dispersing on lattice surface or small particles are beneficial for catalytic activity, but larger particles are adverse. As such, improving preparation methods to delay the generation and growth of $\mathrm{CeO}_{2}$ phase may be effective for further improvement of activity. But beyond that, more researches still need to go further in order to improve the catalytic efficiency of NO transformation. For example, effective support materials which can dramatically promote the activity of Ce-doped $\mathrm{LaBO}_{3}$ catalysts still need to be studied. On the basis of Ce-doped $\mathrm{LaBO}_{3}$, partial substitution of the A and/or B cations by cations on different oxidation states should also be attempted. Photocatalytic efficiency of $\mathrm{La}_{0.7} \mathrm{Ce}_{0.3} \mathrm{FeO}_{3} /$ ATP that we mentioned previously can reach as high as $80 \%$ at room temperature. This make us get some great inspiration: in addition to improving catalysts, the reaction conditions must also be concerned.

For $\mathrm{LaBO}_{3} / \mathrm{CeO}_{2}$ catalysts, promotion mechanism is still not clearly explained. However, comparing with $\mathrm{CeO}_{2}$ support or pure $\mathrm{LaBO}_{3}$ perovskite catalyst, the catalytic activities of the majority of supported catalysts are enhanced. The simple preparation methods provide a feasible scheme for improvement of catalytic activity of $\mathrm{LaBO}_{3}$ perovskites.

\section{Conflicts of interest}

Authors declare no conflict of interest.

\section{Acknowledgements}

This work was financially supported by Natural Science Foundation of Xinjiang, China, Grant No. 2016D01A073. This work was also financially supported by Recruitment Program of Global Experts, and the Director Foundation of XTIPC, CAS, Grant No. 2015RC011.

\section{References}

1 J. Li, S. Wang, L. Zhou, G. Luo and F. Wei, Chem. Eng. J., 2014, 255, 126-133.

2 V. Ferrer, D. Finol, R. Solano, A. Moronta and M. Ramos, J. Environ. Sci., 2015, 27, 87-96.

3 M. Li, V. G. Easterling and M. P. Harold, Appl. Catal., B, 2016, 184, 364-380.

4 N. Imanaka and T. Masui, Appl. Catal., A, 2012, 431, 1-8.

5 A. Fritz and V. Pitchon, Appl. Catal., B, 1997, 13, 1-25.

6 S. Roy, M. S. Hegde and G. Madras, Appl. Energy, 2009, 86, 2283-2297.

7 M. Iwamoto and H. Hamada, Catal. Today, 1991, 10, 57-71.

8 M. Iwamoto, H. Furukawa, Y. Mine, F. Uemura, S. Mikuriya and S. Kagawa, J. Chem. Soc., Chem. Commun., 1986, 16, 1272-1273.

9 T. Selleri, F. Gramigni, I. Nova and E. Tronconi, Appl. Catal., $B, 2018,225,324-331$.

10 R. Burch and M. D. Coleman, Appl. Catal., B, 1999, 23, 115121.

11 T. Chafik, D. I. Kondarides and X. E. Verykios, J. Catal., 2000, 190, 446-459.

12 Z. Wang, Z. Qu, X. Quan, Z. Li, H. Wang and R. Fan, Appl. Catal., B, 2013, 134, 153-166.

13 Z. Wang, Z. Qu, X. Quan and H. Wang, Appl. Catal., A, 2012, 411, 131-138.

14 L. Chmielarz, P. Kustrowski, A. Rafalska-Lasocha and R. Dziembaj, Appl. Catal., B, 2005, 58, 235-244.

15 Q. Zhang, Y. Huang, S. Peng, Y. Zhang, Z. Shen, J. Cao, W. Ho, S. C. Lee and D. Y. H. Pui, Appl. Catal., B, 2017, 204, 346-357.

16 Y. Niu, T. Shang, S. Hui, X. Zhang, Y. Lei, Y. Lv and S. Wang, Fuel, 2016, 185, 316-322.

17 C. Zhou, Z. Feng, Y. Zhang, L. Hu, R. Chen, B. Shan, H. Yin, W. G. Wang and A. Huang, RSC Adv., 2015, 5, 28054-28059.

18 Z. Li, M. Meng, Q. Li, Y. Xie, T. Hu and J. Zhang, Chem. Eng. J., 2010, 164, 98-105.

19 X. Guo, M. Meng, F. Dai, Q. Li, Z. Zhang, Z. Jiang, S. Zhang and Y. Huang, Appl. Catal., B, 2013, 142, 278-289.

20 J. Chen, M. Shen, X. Wang, G. Qi, J. Wang and W. Li, Appl. Catal., B, 2013, 134, 251-257.

21 J. Chen, M. Shen, X. Wang, J. Wang, Y. Su and Z. Zhao, Catal. Commun., 2013, 37, 105-108.

22 A. E. Giannakas, A. K. Ladavos and P. J. Pomonis, Appl. Catal., B, 2004, 49, 147-158. 
23 R. Q. Long and R. T. Yang, Appl. Catal., B, 2000, 27, 87-95. 24 A. Logan and M. Shelef, J. Mater. Res., 1994, 9, 468-475.

25 S. Keav, S. K. Matam, D. Ferri and A. Weidenkaff, Catalysts, 2014, 4, 226-255.

26 A. Ashok, A. Kumar, R. R. Bhosale, F. Almomani, S. S. Malik, S. Suslov and F. Tarlochan, J. Electroanal. Chem., 2018, 809, 22-30.

27 K.-Y. A. Lin, Y.-C. Chen and Y.-F. Lin, Chem. Eng. Sci., 2017, 160, 96-105.

28 M. A. Pena and J. L. G. Fierro, Chem. Rev., 2001, 101, 19812017.

29 V. M. Goldschmidt, Naturwissenschaften, 1926, 14, 477-485.

30 N. Labhasetwar, G. Saravanan, S. K. Megarajan, N. Manwar, R. Khobragade, P. Doggali and F. Grasset, Sci. Technol. Adv. Mater., 2015, 16, 036002.

31 S. Ponce, M. A. Pena and J. L. G. Fierro, Appl. Catal., B, 2000, 24, 193-205.

32 R. Leanza, I. Rossetti, L. Fabbrini, C. Oliva and L. Forni, Appl. Catal., B, 2000, 28, 55-64.

33 G. Saracco, F. Geobaldo and G. Baldi, Appl. Catal., B, 1999, 20, 277-288.

34 B. Zhao, R. Ran, L. Sun, Z. Yang, X. Wu and D. Weng, Catal. Commun., 2018, 105, 26-30.

35 Z. Guguchia, T. Adachi, Z. Shermadini, T. Ohgi, J. Chang, E. S. Bozin, F. von Rohr, A. M. dos Santos, J. J. Molaison, R. Boehler, Y. Koike, A. R. Wieteska, B. A. Frandsen, E. Morenzoni, A. Amato, S. J. L. Billinge, Y. J. Uemura and R. Khasanov, Phys. Rev. B, 2017, 96, 094515.

36 S. Khan, R. J. Oldman, C. R. A. Catlow, S. A. French and S. A. Axon, J. Phys. Chem. C, 2008, 112, 12310-12320.

37 S. A. French, C. R. A. Catlow, R. J. Oldman, S. C. Rogers and S. A. Axon, Chem. Commun., 2002, 2706-2707.

38 K. Huang, H. Y. Lee and J. B. Goodenough, J. Electrochem. Soc., 1998, 145, 3220-3227.

39 B. Tofield and W. Scott, J. Solid State Chem., 1974, 10, 183194.

40 J. Topfer and J. B. Goodenough, J. Solid State Chem., 1997, 130, 117-128.

41 V. MathieuDeremince, J. B. Nagy and J. J. Verbist, Catalysis and Automotive Pollution Control III, Stud. Surf. Sci. Catal, 1995, 96, 393-404.

42 R. Zhang, N. Luo, B. Chen and S. Kaliaguine, Energy Fuels, 2010, 24, 3719-3726.

43 N. Erdenee, U. Enkhnaran, S. Galsan and A. Pagvajav, J. Nanomater., 2017, 9120586.

44 L. Forni, C. Oliva, F. P. Vatti, M. A. Kandala, A. M. Ezerets and A. V. Vishniakov, Appl. Catal., B, 1996, 7, 269-284.

45 Y. Wen, C. Zhang, H. He, Y. Yu and Y. Teraoka, Catal. Today, 2007, 126, 400-405.
46 J. Zhu, Y. Zhao, D. Tang, Z. Zhao and S. A. C. Carabineiro, J. Catal., 2016, 340, 41-48.

47 X. Zhu, S. Zhang, Y. Yang, C. Zheng, J. Zhou, X. Gao and X. Tu, Appl. Catal., B, 2017, 213, 97-105.

48 M. Ghasdi, H. Alamdari, S. Royer and A. Adnot, Sens. Actuators, B, 2011, 156, 147-155.

49 X.-P. Xiang, L.-H. Zhao, B.-T. Teng, J.-J. Lang, X. Hu, T. Li, Y.-A. Fang, M.-F. Luo and J.-J. Lin, Appl. Surf. Sci., 2013, 276, 328-332.

50 A. E. Giannakas, A. A. Leontiou, A. K. Ladavos and P. J. Pomonis, Appl. Catal., A, 2006, 309, 254-262.

51 Y. Qin, L. Sun, D. Zhang and L. Huang, Catal. Commun., 2016, 79, 53-57.

52 H. Zhang, X. Li, Y. Hui, L. Yu, Q. Xia, S. Luo and C. Yao, J. Mater. Sci.: Mater. Electron., 2017, 28, 9371-9377.

53 H. Q. Ma, H. M. Zhu, X. Tan, J. Y. Zhang and L. Chang, J. Rare Earths, 2004, 22, 357-360.

54 M. Alifanti, J. Kirchnerova and B. Delmon, Appl. Catal., A, 2003, 245, 231-243.

55 B. He, Q. Song, Q. Yao, Z. Meng and C. Chen, Korean J. Chem. Eng., 2007, 24, 503-507.

56 T. Nitadori, S. Kurihara and M. Misono, J. Catal., 1986, 98, 221-228.

57 H. He, M. Liu, H. Dai, W. Qiu and X. Zi, Catal. Today, 2007, 126, 290-295.

58 A. Tarjomannejad, A. Farzi, M. J. I. Gomez, A. Niaei, D. Salari and V. Albaladejo-Fuentes, Catal. Lett., 2016, 146, 23302340.

59 S. Wu, C. Song, F. Bin, G. Lv, J. Song and C. Gong, Mater. Chem. Phys., 2014, 148, 181-189.

60 A. Di Benedetto, G. Landi, V. Di Sarli, P. S. Barbato, R. Pirone and G. Russo, Catal. Today, 2012, 197, 206-213.

61 R. You, Y. Zhang, D. Liu, M. Meng, Z. Jiang, S. Zhang and Y. Huang, Chem. Eng. J., 2015, 260, 357-367.

62 C. Orak, S. Atalay and G. Ersoz, Sep. Sci. Technol., 2017, 52, 1310-1320.

63 X. Li, Y. Yin, C. Yao, S. Zuo, X. Lu, S. Luo and C. Ni, Particuology, 2016, 26, 66-72.

64 X. Yin, L. Hong and Z. L. Liu, J. Membr. Sci., 2006, 268, 2-12. 65 R. Zhang, W. Yang, N. Luo, P. Li, Z. Lei and B. Chen, Appl. Catal., B, 2014, 146, 94-104.

66 H. Einaga, W. Yoshida, C. Lee and K. Kusaba, Catal. Lett., 2016, 146, 2495-2503.

67 M. Alifanti, M. Florea and V. I. Parvulescu, Appl. Catal., B, 2007, 70, 400-405.

68 Y. Wang, Y. Xue, C. Zhao, D. Zhao, F. Liu, K. Wang and D. D. Dionysiou, Chem. Eng. J., 2016, 300, 300-305.

69 M. Alifanti, J. Kirchnerova and B. Delmon, Appl. Catal., A, 2003, 245, 231-244. 